\title{
THE JIHAD AND THE ISLAMIZATION IDEAL: A RECONSIDERATION OF THE CASE OF ILORIN EMIRATE, C. 1823-1900.
}

(Received 18 December 2003; Accepted 14 January 2004)

\section{ABSTRACT}

In classical islamic tradition, one of the basic rationale for undertaking a jihad is to expand the dar-a/-Is/am. The jihad which was started in Hausaland in the northern part of the later Nigerian region was no exception to this Islamic ideal. This study has attempted to re-examine critically what the authorities of llorin Emirate, one of the resultant emirates from the jihad, did with respect to that incumbent proselytizing duty during the nineteenth century in their conquered but essentially animist southern fiefs. The reconsideration has been deemed necessary in view of the conclusions expressed in some major secondary works, to the effect that the authorities of the emirate failed to pay attention to the Islamization of these fiefs.

KEY WORDS: Jihad, Islam, Proselytization, Dar-al-Is/am

\section{INTRODUCTION}

A wave of jihads spread through the Western Sudan during the nineteenth century. One of them was the jihad which was started in Hausaland, in the northern segment of later Nigerian region, in 1804 by the Fulani Islamic scholar, Uthman bin Fudio. In line with classical Islamic tradition, one of the cardinal duties which bin Fudio enjoined on his cojihadists was to spread Islam in the unbelievers' or non-Muslim territories (Willis, 1967; Last, 1967). As far as the foundingfathers of the Sokoto Caliphate (which resulted from the jihad) were concerned, attainment of political power in various places by the jihadists was valuable primarily in so far as it would help in the promotion and spread of Islam in those places. In this respect, if must be noted that as soon as each of the constituent emirates of the caliphate was founded, one of the duties which the Caliph at Sokoto enjoined upon its emir was to expand the frontiers of Islam.

By about 1823, the llorin Emirate had been established on the northern fringes of Yorubaland and it subsequently became one of the emirates of the Sokoto Caliphate. Later, especially between the 1830s-1850s, the Ilorin Emirate conquered and incorporated vast territorial and demographic areas of basically animist Yoruba-speaking peoples in its southern direction. This study has attempted a critical re-examination of what the authorities of the emirate did, during the nineteenth century, with respect to their Islamic proselytization duty, in the animist southern fiefs of the emirate. The rationiale for the choice of llorin Emirate in particular for the study is the current weight of opinion which is observable in existing secondary works, to the effect that the authorities failed to consciously and vigorously prosecute the spread and growth of Islam in their conquered non-Muslim territories throughout the nineteenth century (Danmole, 1980; Raji, 1990; Banwo, 1995). Another important rationale for its choice is the fact that these animist territories contained a considerable physical and demographic proportion (more than half) of the total physical and demographic size of the emirate.

ISLAMIC PROSELYTIZATION VIS-A.VIS STRUGGLE FOR SURVIVAL, C. 1823-1900

In 1796, the Alaafin of Old Oyo Empire appointed one of his leading military officers called "Afonja" as the Aare Ona Kakanfo (that is, "generalissimo") of the empire. In that capacity. Afonja was required to reside at llorin, the northernmost outpost of the empire, in order to ward off enemy attacks from that insecure frontier. Being ambitious, Afonja decided to take advantage of the prevalent instability within the metropolis of the empire to carve out for himself an independent domain (as some of the other provincial chiefs were busy doing), with llorin as its base. In this secessionist bid against his suzerain the Alaafin, Afonja sought and got the assistance, in men and Islamic charms, of an itinerant Fulani Muslim scholar then based at llorin, called 'Alim al-Salih. Afonja succeeded in his palace coup and declared himself and llorin independent of the Alaafin (Hermon-Hodge, 1929; Hogben, 1930; Atanda, 1971; Law, 1977). He then proceeded to bring some towns in the north-east of the empire, such as Ejigbo, Igbon and Iresa, under his control. Afonja soon felll out with his Fulani-Muslim allies at llorin after the death of their leader, al-Salih, about 1823. In the struggle between the two sides over the rulership of llorin, Afonja was defeated and killed and an emirate was established at llorin under al-Salih's elder son, Abdulsalam, as its first emir.

Consequent upon the foregoing circumstances which surrounded its foundation, llorin Emirate had to face a protracted political and military struggle for existence and survival during the rest of the nineteenth century. The struggle started in earnest as the authorities of the Old Oyo Empire embarked on a series of military onslaughts which were aimed at "...a total destruction of liorin under Fulani leadership and returning llorin to both Yoruba and Oyo's imperial fold' (Balogun, 1978). The last such effort was the Eleduwe War o' $1835 / 1836$ in which a combination of Oyo's imperial forces anc the forces of their Batombu allies seriously threatened the survival of the emirate (Hermon-Hodge, 1929. Akinwumi 1992). The Emir, Abdulsalam, had to appeal to his immediate suzerain in the Sokoto caliphal set-up, the Emir of Gwandu. Ibrahim Khalil, for military assistance (Balogun, 1978). So grave was the danger posed for the emirate that Emir Khalil personally led the joint forces of Gwandu and Sokoto to aid Ilorin and decisively defeat Oyo's allied forces (Anene, 1965; Akinwumi, 1992). llorin followed up the victory by invading and sacking the empire's capital, and its inhabitants fled in various directions, thus completing the ultimate demise of the Old Oyo Empire. That resounding victory of Ilorin over Oyo's forces notwithstanding, the very fact of the founding of llorin Emirate in Yoruba territory (all the other emirates were founded in nonYoruba areas) made it inevitable that the emirate should be deeply involved in the politics of Yorubaland, as would be discussed later on.

Owing to a combination of political, military, strategic and economic considerations which are not directly relevant to the thrust of this study, the authorities of the emengent llorin Emirate embarked on wars of conquest in the Ekiti, Igbomina and Ibolo territories to the south-eastern and south-western directions. (Awe, 1864; NNAK IIOrProf 6338). The wars led to the incorporation, into the emirate, of vast areas and populations, especially between the 1830 s and 1850 s. Like the generality of the Yoruba culture group at that time, the people of these southern areas were animists who practised 
some formp of African Religions (AR). According to M. Last, however, one of the overriding motives for llorin's incursions into these southern territories was to continue the jihad and to thereby spread Islam as was incumbent on every emirate in the Sokofo Caliphate (Last, 1967). Having conquered the territories, the emirate authorities put in place there some form of administration. In theory, the Emir of llorin was the political, military, fiscal, judicial and religious head of these places and of the other areas of the emirate. In practice, however, the people of the southern fiefs were left to the devices of their pre-llorin conquest traditional rulers in matters concerning their internal affairs. The most important requirements from the people by the llorin authorities were the prompt payment of taxes and tributes (in cash and kind) and the supply of military subscriptions for llorin's wars. To ensure effective performance of the requirements, the areas were parcelled informally into fiefs. The fiefs were assigned to the emirs, the emirs' sons and other members of the llorin aristocracy, such as the four Balogun (war-commanders) as their fief-holders. The fief-holders resided at llorin. As absentee landlords, therefore the fief-holders appointed their residential agents called ajele" to perform their functions on their behalf by seeing to it that the fiefs performed the above requirements (NNAK lorProf 739/1917). The people of the fiefs, however, still had the latitude to conduct and control their internal affairs as they pleased. For example, they were free to select and appoint their traditional rulers and to practise their various forms of African Religions.

The establishment of the foregoing minimal administration in the conquered southern areas went on pari pasu with llorin's continued expansionist and defensive wars, for it must be noted that llorin's defeat of the 'Old Oyo Empire in $1835 / 1836$ did not put an end to the struggle for survival by llorin Emirate. The demise of the empire had led to a power contest among some older as well as some nascent states in Yorubaland for the filling of the vacuum which had been created by the demise. The states included Ibadan, ljaye and lle-lfe. By the late 1830s, Ibadan, one of the new states, had gained indisputable ascendancy over the other contestants. That state of affairs made a clash between Ibadan and llorin inevitable as both of them had imperialist and expansionist designs in Yoruba land (Danmole et al, 1985). Most probably out of enlightened self-interest, Ibadan also assigned itself the responsibility of ending the menace of alien Fulani rule in llorin and reclaiming llorin for Yorubaland. Then came the actual clash between Ibadan and Ilorin, which culminated in the decisive defeat of the latter in the Osogbo War of 1838. The defeat put an end to llorin's expansionist designs in the Ibolo sector of Yorubaland (Akintoye. 1977:34). Ilorin therefore concentrated its expansionist efforts on the Ekiti and Igbomina territories while it had to simultaneously contend with the military activities of Ibadan and ljaye which both "...began a systematic rolling back of the llorin domination over the (lbolo) Osun districts..." (Akintoye, 1967.34). During the next four decades, llorin also busied itself with other military and strategic engagements, such as the struggle to get firmly entrenched in northern Ekiti against stiff opposition there by Ibadan. By 1878, however, the Ekitiparapo War broke out between the north-eastern Yoruba peoples and their Ibadan suzerains. For reasons of its political interests, llorin got involved in the war - first, as an ally of the Ekitiparapo Confederacy in an attempt to liquidate its rival and enemy. Ibadan, and, later, as one of the major belligerents in the Offa sector of the war from 1879 - 1887. Then followed the protracted peace negotiations, by the mediating officials of the British Colony of Lagos, in the war-torn ibolo sector of Yorubaland, between the Ibadan and llorin belligerents. The negotiations culminated in the peace treaty of March 1893. The period 1893 - 1900 was characterized by increasing tension between the British authorities and the florin Emirate authorties. The resultant crisis culminated in the British military expedition against llorin on $25^{\text {th }}$ January, 1897. This was followed up with the establishment of British colonial rule over the emirate, through the signing of a treaty to that effect by both parties on $18^{\text {In }}$ February, 1897. (Adeleye, 1971).

The essence of the foregoing analysis is to adequately demonstrate the key pressing and inevitable issues with which the authorities of the newly-established llorin Emirate were preoccupied throughout the rest of the nineteenth century. It becomes pertinent at this juncture to critically examine how the emirate authorities fared during that century in their incumbent duty of spreading Islam in the nonMuslim southern fiefs of the emirate. For this we have three in-depth secondary works on the study area as our authority. One is the unpublished doctoral thesis of H.O. Danmole titled: "The Frontier Emirate: A History of Islam in llorin". The second is an unpublished Master's thesis by $A . O$. Y. Raji titled: "Demystifying the Proselytizing Mission: A Study of llorin Overrule in Igbominaland, c. $1835-1968$ ". Thirdly we have the published study by $A$. O. Banwo titled: "The $19^{\text {th }}$ Century Ilorin Wars and the Growth of Islam in Yorubaland: A ReAssessment." According to Danmole who has the most liberal conclusions out of the three authors, the llorin authorities concentrated on the political and economic aspects of their relationship with their non-Muslim southern fiefs and made cultural or Islamic pressure on the fiefs minimal (Danmole, 1980). He explained further that it was through both direct and indirect proselytization efforts of some groups other than the llorin emirate authorities that Islam spread to and grew in a few areas of the southern fiefs. The groups were Muslim Fulani herdsmen and farmers and llorin mallams; and the affected southern fiefs in this respect, according to him, were Ajase-Ipo and Igbaja areas (Danmole, 1980; Danmole, 1983). In respect of A.O.Y. Raji, his conclusions have been quoted here extensively, for the purpose of the later analysis in this study. His position is as follows: (1) ".llorin never made any concrete proselytizing bid to minister Islam to the Igbomina." (Raii 1990:87). (2) "...people of the southern districts of thorin Emirate were left unconverted to Islam by their emirate suzerains." (Raji, 1990:136). (3) "... efforts were not known to have been made by the llorin elite to spread Islam even in the southern part of the emirate throughout the nineteenth century." (Raji, 1990:94) (4) "Generally, the religious enthusiasm of the Fulani [authorities of the emirate - insert mine] had ebbed by the second decade of the $19^{\text {th }}$ century... (Raji, 1990:90). Writing in a similar vein although more from the perspective of economic exploitation, of the southern fiefs, by the llorin aristocracy for the purpose of enhancing and consolidating their political power in the emirate, A. O. Banwo made his conclusions as follows:

(1) 'The colonies' main function among others, included the payment of taxes, tributes and tolls, and the regular supply of food crops, slaves and other forms of goods and services decreed by the aristocracy. The supply of these forms of surplus became the primary responsibility while the spread of Islam became relegated." (Banwo, 1995:88). (2) "The effect of the non-commitment of the llorin aristocracy to the growth of Islam in Yorubaland clearly manifested in the socio-political development of the emirate in the $19^{\text {th }}$ century and beyond." (Banwo, 1995:88) (3) There is a possibility that political opportunism and the quest for economic power were the compelling motives, on the part of the aristocracy, for llorin's wars especially "... when viewed within the context of the unserious commitment by the llorin aristocracy at "dipping the Koran into the sea..." (Banwo, 1995:94)

It is deemed necessary to undertake a critical appraisal of the above conclusions by the three authors because it does not seem entirely correct to opine that the emirate authorities made no committed effort at islamic proselytization in the non-Muslim southern fiefs during the nineteenth century. We have it on the authority of $K . V$. Elphinstone in his Gazetteer of llorin Province, and corroborated by archival records. that at least one of the emirs. Emir Zubeiru (c. 1861 - 1868), had an Islamic proselytizing zeal. According to Elphinstone, "Zubeiro [sic] was a begotten Moslem; he burnt the juju and juju houses and swore that he 
would put to death all pagans; an immense wave of Islam swept over the country in consequence." (Ephinstone, 1972; NNAK IlorProf 53). In fact, his people acknowledged his Islamic zeal with this epithet which they coined to describe him: "A gbona bi eleko idaj" meaning, literally, "he was as hot as a pot of steaming early morning pap", in reference to his Islamic fervour. (Hogben, 1966:295). Yet, according to Raji above, that was part of the period when the religious enthusiasm of the llorin aristocracy was supposed to have ebbed. In fact, archival records inform us that it was during Zubeiru's reign that a recalcitrant Oore or Oba of Otun in the Ekiti area of the southern fiefs, cognizant of the emir's proselytizing fervour, decided to appease him and return to the good books of his emirate overlords by declaring (even if it was merely a nominal declaration, as was quite possible) his conversion to Islam (NNAK IlorProf 53). With the declaration, the emir forgave him for having earlier on invited the Ibadan to aid him militarily against Aaye, a neighbouring Ekiti settlement. (In the process, the Ibadan had seized the opportunity to also drive out the llorin ajele in Otun and replace him with their own ajele).

Moreover, Raji informed us that some Igbomina Oba (and most probably, some Ekiti and Ibolo Oba as well) became nominally converted to Islam during the nineteenth century because they were aware that at least a tacit allegiance to Islam was necessary to win the favour of their emirate suzerains (Raji, 1990).In Raji's words, "...We know that with the creation of Ilorin Emirate, Islam became the gateway to the Fulani (llorin) world and conversion to it was the price for entry." Raji, 1990:95). Such nominal and diplomatic avowal of conversion by some of the traditional rulers of the southern fiefs demonstrates that these animist traditional rulers and people realized that their emirate overlords were interested in the spread of Islam to their areas. It would seem inappropriate to make blanket conclusions to the effect that the llorin aristocracy during the nineteenth century, were disinterested in, made no concrete effort at, or relegated, Islamic proselytization in their animist southern fiefs. A more realistic appraisal of the issue would seem to be that some peculiar political and military circumstances led to the establishment of the emirate right on Yoruba soil. Consequently, the emirate became preoccupied, for the rest of that century. with a series of wars for the very survival of the emirate during that period of internecine wars in Yorubaland. The wars, in turn, precluded the possibility of the llorin authorities being able to simultaneously devote time, resources and attention to a consistent and vigorous policy of Islamic proselytization in their non-Muslim southern fiefs. Viewed in this light, even the expansionist wars in Yorubaland on which the emirate embarked could be interpreted, in the final analysis, as wars of survival because often, the best form of defence is to undertake the initiative in the offensive sphere. As the Yoruba proverb has it "Igi ganganran ma gu mi l'oju, a t'okere laa $t i$ wo". Meaning. "If you don't want something to harm you, then you have to take precautionary steps early enough."

Any overt and consistent policy of Islamizing the fiefs was potentially capable of leading to their revolt or, at least, a spirited resistance by the southern fiefs against llorin Emirate. Such would have been a very costly development for the emirate. For one thing, it would have involved the emirate in war on an additional front, with all the implications in terms of human and material resources. This view is underscored by the point made by T. G. O. Gbadamosi with respect to the spread of Islam among the entire Ekiti-speaking peoples, but which could be correctly extended to the Ibolo and Igbomina southern fiefs of llorin Emirate as well. According to him, one of the two major obstacles which confronted the spread of Islam among the Ekiti throughout the nineteenth century was that their first contact with Islam had been through the wars and raids of llorin, a militant Muslim state, and this therefore generated considerable opposition, among the Ekiti, against llorin and the religion with which it was associated (Gibadamosi, 1978). Furthermore, such a resistance, while it lasted, would have robbed the emirate of much-needed taxes tributes and military subscriptions from the fiefs, and thereby weakened the emirate economically and militarily.

Finding themselves confronted with making a choice between vigorous Islamic proselytization and the very survival of the emirate, the llorin aristocracy wisely chose the latter option. The attempt by Emir Shitta to consciously spread Islam to non-Muslim peoples (in this case, specifically to the Alaafin and, by logical extension, also to the people, of Old Oyo Empire) had been a major cause of the Eleduwe War by Alaafin Oluewu against llorin in 1835/1836 (Johnson, 1978). Also, when during the $1840 \mathrm{~s}$, Ayingusin, the Oloro of Oke-Ora (Oke-Ola) Oro among the Igbomina of the southern fiefs became a Muslim, he was deposed and exiled by his people in protest (Elphinstone, 1972; Danmole, 1983). It therefore sounds quite expedient for the Ilorin aristocracy to have gradually come to the conclusion not to make "any concrete bid to minister Islam" to the people of their southern fiefs. Danmole itemized two important issues in the relationship between llorin and the fiefs viz, unresolved hostilities and incomplete conquests (Danmole, 1983). The aristocracy might therefore have decided that in the difficult and hostile circumstances which the emirate faced both internally and externally, a policy of vigorous Islamic proselytization would be counter-productive to the overall interests of the emirate in the short run as well as in the long run.

In matters of foreign policy. Banwo gave an in-depth picture of the continually shifting nature of llorin's alliances with Muslims and non-Muslims alike. From this, he buttressed his view above that political and economic interests, and not Islamic zeal, determined, for the llorin aristocracy; the pattern of the emirate's alliances (Banwo, 1995). This does not seem to have been the case. Rather, the aristocracy seemed to have been trying to ensure the emirate's survival and if possible, expansion, at all costs and by all means since in matters of inter-state politics and diplomacy generally, "the end justifies the means". This point is buttressed by $H$. O. Danmole's summation of the issue of liorin's shifting alliances when he referred to the common dictum that it was a case of having no permanent friends (or enemies as the case may be) but, rather, permanent interests where matters of external relations were concerned (Danmole. 1983b). As for Banwo's copious discussion of the extensive appropriation of surplus capital from the fiefs by the llorin aristocracy instead of prosecuting the jihad, this needs not be surprising because the prosecution of warfare both in the past and present times required and still requires a heavy capital outlay (Banwo, 1995). Finally, the three major works which have been appraised in this study are unanimous on the fact that the duty of evangelizing llorin's southern fiefs was undertaken by Muslim scholars and Mallams, but not by the llorin aristocracy. This seems understandable in spite of the on-going wars discussed above. Missionaries, be they Islamic or Christian missionaries, can and do operate even in war zones. They regard the risks and sacrifices involved in such an undertaking as an integral part of their divinely ordained duty. For a state, however, the equation is not as simple as that. It must be emphasized that it was virtually impracticable for a state which was constantly embroiled in warfare during the nineteenth century, as llorin Emirate was, to simultaneously prosecute vigorous evangelization as a matter of state policy. The situation today with the great technological advances such as nuclear and biological warfare weapons might, of course, be different.

With the benefit of hindsight of developments in the southern fiefs during the colonial era (then called "southern districts"), $1900-1960$, one is inclined to conclude that had the circumstances been different during the nineteentr century, the llorin aristocracy would have concretely prosecuted the spread of Islam in the non-Muslim areas. Two examples will suffice here to show how the aristocracy utilized the stability and security which were provided by the colonial state to consciously, consisterntly and overtly prosecute the 
spread of Islam in the southern districts. First could be cited the fact that the Emirs of Ilorin, in their capacity as Sole Native Authority in Ilorin Emirate or Division, regularly advised the colonia government against granting permission to the Christian missionaries to establish and operate in the southern districts (Afolayan, 1986). Secondly, in 1950, Gabriel Adeoye, who had been duly selected by the kingmakers and people of Oke-Origbin (among the Igbomina) as their Oba was rejected by the Emir and, therefore, by the government, because he was a Christian (Raji, 1990). The Emir appointed and turbanned instead a Muslim contestant, Jimoh Olaoye, whom the kingmakers and townspeople had rejected on the grounds that he was a leper and was also not a rightful claimant to the stool (Raji, 1990). The essence of such measures was to deter other members of the aristocracy in particular and the people in general in the southern districts from conversion to Christianity, as well as to encourage their conversion to Islam. These pro-Islam efforts of the Emirs of llorin during the colonial period cannot be interpreted as having been due to the aristoctacy having suddenly woke up from their disinterestedness of the preceding century. It was a matter of now exploiting the favourable circumstances which surrounded the emirate to prosecute the spread of Islam in the non-Muslim ifiefs, as was incumbent upon them.

\section{CONCLUSION}

The Ilorin Emirate was one of the emirates of the Sokotd Caliphate, which resulted from the early nineteenth century jihad in the northern part of later Nigerian region. In classical Islamic tradition, the Ilorin Emirate, like the other emirates in the caliphate, was expected to continue the jihad by spreading Islam into non-Muslim areas. The weight of opinion in some existing major secondary works is that the authorities of llorin Emirate failed to carry out this requirement but instead concentrated on their personal interests and the political and economic consolidation in the emirate. The conclusion from this study, however, is that contrary to that view, the difficult and hostile circumstances in which the emirate found itself throughout the nineteenth century precluded the possibility of the aristocracy sparing time, resources and attention to vigorous Islamic proselytization.

\section{NOTES AND REFERENCES}

Adeleye, R. A., 1971. Power and Diplomacy in Northern Nigeria, $1804-1906$. The Sokoto Caliphate and its Enemies. (London: Longman), pp. 185 - 187.

Afolayan, F. op.cit., p. 5. See also p. 7. This was a common policy among the Emirs in Northern Nigeria during the colonial period. In the case of Igbominaland, however, the emirs did not quite succeed with the colonial government in this policy. See ibid., passim.

Akintoye, S. A., 1977. Revolution and power Politics in Yorubaland 1840 - 1893: Ibadan Expansion and the Rise of Ekitiparapo. (London: Longman, 1971, 1977 repr.), p. 34.

Although Raji's work is focused on the Igbomina, nevertheless, he often extended his conclusions to the other peoples of the southern fiefs of llorin Emirate.

Balogun, S. A., 1978. "Historical Significance of llorin - A Preliminary Survey." Confluence, I, 1, June p. 18.

Banwp, A. O, op.cit., p. 94.

Balogun, S. A 1978, op.cit., p. 19.

Banwo. A. O., 1983. op.cit., pp. $89-91$.

Banwo, A. O. op.cit.., p. 88.
Danmole, H. O., Thesis, op.cit., p. 136.

Danmole, H. O., 1983, op.cit., p. 9.

Danmole, H. O., 1983. "The External Relations of llorin in the Nineteenth Century." Paper presented at the $28^{\text {th }}$ Congress of the Historical Society of Nigeria, University of llorin, llorin. $1^{\text {st }}-6^{\text {th }}$ Merch, 1983, p. 10. See also pages $10-18$ for his illuminating analysis of the factors which influenced Ilorin's shifting alliances during the nineteenth century.

Elphinstone, K. V. op.cit., p. 15; and Danmole, H. O., 1983. op.cit., p. 8. Some writers, such as F. Afolayan, put the date at the $1860 \mathrm{~s}$. Since Elphinstone tells us that the event occurred during the reign of Emir Shitta, which ended about 1861, then the 1840s seems to be the more probable date. See F. Afolayan. "Religion, State and Society in Colonial central Nigeria: The Igbomina Experience." Paper presented at the $31^{\text {st }}$ Congress of the Historical Society of Nigeria, University of Ife (now Obafemi Awolowo University). lle-lfe, $18^{\text {th }}-24^{\text {th }}$ May, 1986, p. 3.

Elphinstone, K. V., 1954. Gazetter of llorin Province. (London: Frank Cass, 1921, 1972 ed.), P. 17; and NNAK ILorProf 53, "Local Government Reform in Ekiti Area of llorin Emirate."

Foe details, see ibid., pp. 135 and 136; and H. O. Danmole. "The Spread of Islam in Ilorin Emirate in the Nineteenth Century. "Journal of the Nigerian Association of Teachers of Arabic and Islamic Studies (NATAIS), II, 2, October 1983, pp. 5-9.

For details, see Danmole, H.O. and Falola, T., 1985. "Ibadan Ilorin Relations in the Nineteenth Century: A Study in Imperial Struggles in Yorubaland. "Transafrican Journal of History, XIV, pp. 21-36.

For variants of the Afonja-al-Salih-Alaafin issue, see, among others, Hogben, S. J., 1971. The Mohammedan Emirates of Northern Nigeria. (London: Oxford University Press, 1930). pp. 151 - 156; H. B. Hermon-Hodge. Gazetteer of llorin Province. (London: George Allen \& Unwin, 1929), pp. $10-17$; S. Johnson History of the Yorubas. (Lagos: C. S. S. Bookshops, 1921, 1978 repr.). pp. $189-200 ;$ R. C. C. Law. The Old Oyo Empire c. 1600 - c. 1836 - A West African Imperialism in the Era of the Atlantic Slave Trade. (Oxford: Clarendon, 1977), pp. 250ff; and J. A. Atanda. "The Fall of Old Oyo Empire: A Reconsideration of its Causes." Journal of the Historical Society of Nigeria (JHSN), V.4, Junepp. $477-490$.

For details of the alliance, see Hermon-Hodge, H. B. 1929, op.cit. pp. 291-294; and Akinwumi, O.D., 1992. "The Oyo - Borgu Military Alliance of 1835: A Case study in the Pre-Colonial Military History."Transafrican Journal of History, Vol. 21, pp. 161-165.

Gbadamosi, T. G. O., 1978. The Growth of Islam among the Yoruba 1841 - 1908. (London: Longman), p. 87.

Hogben, S. J. and Kirk-Greene, A. H. M., 1966. The Emirates of Northern Nigeria. (London: Oxford University Press), p. 295.

Ibid., p. 136.

Ibid. p. 94. 
Ibid. p. 90.

Johnson, S., Op.cit. p. 259.

Last, M. 1967, op.cit., p. 56.

Loc. Cit.; Akinwumi, O. D. 1992, op.cit and J. C. Anene. 1965. "The Eclipse of the Borgawa." JHSN, III, 2, p. 215.

Loc.cit.

Loc.cit.

Loc.cit.

NNAK ILorProf 739/1917, "History of Awtun, llorin District, as told by Usman Mijindadi, Ajele at Otun [sic] from c. 1864-1897." The Southern fiefs of Ilorin Emirate consisted of some Ekiti, Igbomina and Ibolo Yoruba peoples.

\section{NNAK ILorProf 53, op.cit.}

Raji, A. O. Y. Thesis, op.cit., p. 87.

Raji, A. O. Y. op.cit., p. 95.

Raji, A. O. Y. op.cit., p. 176. Such a hostile policy towards Christian traditional rulers was, again, a common feature of the entire Northern Nigeria. For such instances, see E.'A. Ayandele. "The Missionary Factor in Northern Nigeria, 1870 - 1918." JHSN, III, 3. December 1966, p. 519; and M. Y. Mangwwat. "The
Missionary Factor and Class Formation in Plateau Province, $1902-1960$." Paper presented at the $31^{\text {st }}$ Congress, op.cit., p. 15.

Raji, A. O. Y. op.cit.

See Banwo, A. O., 1983. op.cit., pages 88 - 91 for the discussion.

The secondary works which will be focused upon here are: (a) Danmole, H. O., 1995. "The Frontier Emirate: A History of Islam in Ilorin." Ph.D. Thesis, University of Birmingham, 1980; (b) A. O. Y. Raji. "Demystifying the Proselytizing Mission: A Study of llorin Overrule in Igbominaland, c. 1835 - 1968." M. A. Thesis, University of llorin, llorin, 1990; and (c) A. O. Banwo. "The $9^{\text {th }}$ Century llorin Wars and the Growth of Islam in Yorubaland: A Re-assessment. "Hamdard Islamicus, XVIII, 1, pp. 85-96.

There was, of course, also a religious consideration, that is, the desire to spread Islam, but that is directly relevant to our concern in this study. For details of those other considerations, see Nigerian National Archives, Kaduna (NNAK) ILorProf 6338, "Notes on History of Igbomina, Ekitis, Ajasse, Awtun, Obbo, and Osi, 1917 - 40;" and B. A. Awe. "The Rise of lbadan as a Yoruba Power, 1851 - 1893." D. Phil. Thesis, Oxford, 1964, p. 128.

Willis, J. R., 1967. "Jihad in Nineteenth Century West Africa." Journal of African History (JAH) VIII, 3, 1967, pp. 395 - 398; and M Last. The Sokoto Caliphate. (Harlow: Longman). 